Relations industrielles

Industrial Relations

\title{
Social Sense in Toronto
}

\section{Ferdinand Vandry}

Volume 5, numéro 5, février 1950

URI : https://id.erudit.org/iderudit/1023330ar

DOI : https://doi.org/10.7202/1023330ar

Aller au sommaire du numéro

\section{Éditeur(s)}

Département des relations industrielles de l'Université Laval

ISSN

0034-379X (imprimé)

1703-8138 (numérique)

Découvrir la revue

Citer cet article

Vandry, F. (1950). Social Sense in Toronto. Relations industrielles / Industrial Relations, 5(5), 49-49. https://doi.org/10.7202/1023330ar

Tous droits réservés @ Département des relations industrielles de l’Université Laval, 1950
Ce document est protégé par la loi sur le droit d'auteur. L'utilisation des services d'Érudit (y compris la reproduction) est assujettie à sa politique d'utilisation que vous pouvez consulter en ligne.

https://apropos.erudit.org/fr/usagers/politique-dutilisation/ 


\title{
SOCIAL SENSE IN TORONTO
}

\author{
Mgr Ferdinand Vandry
}

I must further say that I am deeply interested in the social-mindedness or social sense that I notice in Toronto. We all know that social and economic life is changing a lot in the world. Everybody hears of new principles and doctrines taught to-day. Some people are unfortunately misled in thinking that the Catholic Church is fighting capitalism, preaching revolution and favoring communism. The truth is that the Church is doing nothing else that teaching the way to avoid the triumph of communism. She is teaching social justice and charity. That means that employers and workers must get closer together in a better understanding of their common problems. Workers must be made to understand that capital is necessary. Without capital, industry would vanish. But the employers must admit that their businesses should be conducted for the good of the community and not only for the profit of stockholders. Workers should be made satisfied and happy, because everybody on this earth has a right to his part of happiness. Make people happy and you destroy communism.

\section{REVIEWS ON INDUSTRIAL RELATIONS}

\section{"DROIT SOCIAL"}

\&DROIT SOCIAL » is a monthly review of about forty pages which studies problems of industrial interorganization and labour, as well as the new forms of economic life in their relations with the legal order. It draws the attention of its readers to the elements of this changing world which is building its domain in the border-lands of public and private law.

This publication usually contains a couple of articles prepared either by law professors chosen from the principal French universities, or by leading officials or functionaries of the Government. These works are of a nature to interest not only specialists in social legislation but also all those who follow closely the contemporary social and legal evolution.

It goes without saying that the greater number of studies published in \&DROIT SOCIAL 》 bear on French problems. But, we find there also some which treat certain facts of the social and legal situation in other countries.

CDROIT SOCIAL 》 is divided into two parts industrial organization and labour. It is in the first that we find the most advanced studies. It is ended always with a report on the economic situation consisting of a summary of the state of the economy at the moment of publication, industrial and agricultural activity, price and money levels, etc. This report is edited by Alfred Sauvy, director of the National Institute of Demographic studies and member of the Economic Council.
To have prosperity and happiness in our country capitalists must understand what their duty is and realize their money must not only profit themselves and the stockholders but also their employees. The Robert Simpson Company is a typical example of such social sense. If all the employers of Canada had the same spirit as Mr. Charles Burton, the President of Simpson Company, there would be nothing to fear from communism in this country.

It appears to me that more and more the large employers of Toronto realize their social obligations. They are largely interested in Canadian social and charitable organizations, such as the Red Cross which is a very meritorious institution. They are also interested in the welfare of their employees. Toronto is clearing the way to social justice and prosperity.

Those are some of the reasons why $I$ have to pay high tribute to the city of Toronto.

Extract from an address delivered at a meeting of Le club anglo-français de Simpson's on November 24,1949 .

The second part contains many headings such as « Jurisprudence récente en matière sociale », « Bibliographie », «Chronologie sociale française», and \& La situation sociale ». There are also, at times, a legislative report, appendices and documents. In this part one finds the texts of certain State orders-in-Council and abundant citations from judicial decisions, of which some are commented upon by a regular contributor to the Review. The three last numbers of «DROIT SOCIAL », i.e. those of June, July-August, and September-October, present a methodical bibliography on the Reform of the Enterprise. This bibliographical effort deals only with the sharing of personnel in the results of the activity of the enterprise and is limited to works and pamphlets published since 1944.

Since October, 1944, «DROIT SOCIAL 》 publishes a supplement entitled \& SECURITE SOCIALE ET PRESTATIONS FAMILIALES ». This aims at studying separately, but always in the spirit of \&DROIT SOCIAL 》, the totality of the problems posed by modern social security policies under the double aspect of indemnification for and prevention of the social risks - sickness, old age, labour accidents, occupational diseases, family responsibilities. The editor of this new review is Monsieur Paul Durand, professor in the Faculty of Law at Nancy and editor of «DROIT SOCIAL 》. On the editorial board, besides many law professors, are such important persons as Monsieur Pierre Laroque, director-general of social security; Doctor Jacques Parisot, president of the technical committee of Action sanitaire et sociale de la sécurité 